\begin{tabular}{|l|}
\hline MAKERS OF \\
CONTEMPORARY THEOLOGY \\
A new series edited by D. E. Nineham and \\
E. H. Robertson. Whilst intended for the \\
non-specialist reader each book in this \\
series is to be written by a specialist author. \\
In this way we hope to combine brevity \\
with depth and simplicity with scholarship. \\
DIETRICH BONHOEFFER \\
by E. H. Robertson \\
TEILHARD DE CHARDIN \\
by Bernard Towers \\
Ready April \\
Already published \\
PAUL TILLICH \\
by J. Heywood Thomas \\
RUDOLPH BULTMANN \\
by Ian Henderson \\
CAREY KINGSGATE PRESS \\
Dept. N.S. \\
6 Southampton Row, \\
London, W.C.1
\end{tabular}

FULL PARTICULARS OF THE

\section{JOURNALS}

PUBLISHED BY THE

CAMBRIDGE UNIVERSITY PRESS

MAY BE HAD FROM

THE MANAGER

CAMBRIDGE UNIVERSITY PRESS

BENTLEY HOUSE

200 EUSTON ROAD

LONDON, N.W.I

\section{THE BAHÁ' FAITH}

As the latest of the revealed religions, with a century's practice in uniting religions and races, this Faith claims attention and study.

\section{MYSTICISM, SCIENCE AND REVELATION}

Glenn Shook, Ph.D.

12s. $6 d$.

A physicist compares the validity of knowledge derived from personal experience, science, and revealed religion.

\section{BAHÃ'U'LLÁH}

Hasan Balyuzi

13s. 6d.

The life of the Founder by a distinguished scholar, including an essay on the Great Figures, who, in every age, link God with man.

THE MISSION OF BAHÁ'U'LLÁH $13 s .6 d$. THE HEART OF THE GOSPEI

(paper) 2s. 6d.

THE PROMISE OF ALL AGES $10 s .6 d$. CHRIST AND BAHÁ'U'LLÁH $10 s$.

George Townshend

These four books lucidly present Bahá'i history and viewpoint-the first in essays, poems, and meditations; the others in consecutive exposition of the Divine redemptive scheme which leads mankind to maturity.

\section{RELIGION FOR MANKIND (paper) $6 s$.}

\section{Horace Holley}

A selection from the writings of a leading exponent of the theory and practice of Bahá'i Administration.

\section{GEORGE RONALD}

5 Barandon St., London, W.11 


\title{
CONTENTS LIST AND INDEX
}

\author{
voL. I ( $1965-6)$
}

'Aristotle and corruptibility: A discussion of Aristotle De Caelo I, xii', article by C. J. F. Williams (Part I), 95, (Part II), 203

"Belief "in" and Belief "that", article by H. H. Price, 5

Brandon, S. G. F., article: 'The origin of death in some Near Eastern religions', 217

'Buddhist mysticism', article by Trevor Ling, I63

'Christian faith, Contemporary philosophy and the', article by I. T. Ramsey, 47

'Contemporary philosophy and the Christian faith', article by I. T. Ramsey, 47

'Corruptibility, Aristotle and: A discussion of Aristotle De Caelo I, xii', article by

C. J. F. Williams, (Part I) 95, (Part II), 203

'Death, The origin of, in some ancient Near Eastern religions', article by S. G. F. Brandon, 217

'Defence of orthodoxy, A', review article by T. A. Roberts, 241

Editorial note, I

EwING, A. C., article: 'Two "Proofs" of God's existence', 29

'Excluding the Supernatural', article by T. R. Miles, I4I

'Farmer, H. H., and John Oman, The theological methodology of', article by Thomas A. Langford, 229

'God's existence, Two "proofs" of', article by A. C. Ewing, 29

'Gospel historicity: Some philosophical observations', article by T. A. Roberts, 185

Gualtieri, A. R., article: 'Truth claims for religious images', I5I

Hägerström, Axel, Philosophy and Religion, book discussion by H. P. Owen, i i 9 Hepburn, R. W., article: 'Questions about the meaning of life', i 25

'Indian religion and philosophy, Recent views of', article by E. G. Parrinder, rog 'Interpretation and mystical experience', article by Ninian Smart, 75

LANGFord, Thomas A., article: 'The theological methodology of John Oman and H. H. Farmer', 229

'Life, Questions about the meaning of', article by R. W. Hepburn, 125

LING, TRevor, article: 'Buddhist mysticism', I63

— review article: 'The major religious traditions: Recent re-assessments', 249

'Methodology, The theological, of John Oman and H. H. Farmer', article by Thomas A. Langford, 229

MrLes, T. R., article: 'On excluding the Supernatural', I4I

'Mystical experience, Interpretation and', article by Ninian Smart, 75 
'Mystical illuminations, On the mystical rejection of', article by R. J. Zwi Werblowsky, I 77

'Mystical rejection of mystical illuminations, On the', article by R. J. Zwi Werblowsky, I 77

'Mysticism, Buddhist', article by Trevor Ling, $16_{3}$

'Near Eastern religions, The origin of death in some', article by S. G. F. Brandon, 217

'Oman, John, and H. H. Farmer, The theological methodology of', article by Thomas A. Langford, 229

'Origin of death in some ancient Near Eastern religions, The', article by S. G. F. Brandon, 217

'Origins of religion, The', review article by E. G. Parrinder, 257

'Orthodoxy, A defence of', review article by T. A. Roberts, 24I

Owen, H. P., book discussion on Philosophy and Religion, by Axel Hägerström, I I 9

Parrinder, E. G., article: 'Recent views of Indian religion and philosophy', rog review article: 'The origins of religion', 257

Philosophy and Religion, by Axel Hägerström, book discussion by H. P. Owen, I I 9

Price, H. H., article: 'Belief "in" and Belief "that" ', 5

"Proofs" of God's existence, 'Two', article by A. C. Ewing, 29

'Questions about the meaning of life', article by R. W. Hepburn, I 25

Ramsey, I. T., article: 'Contemporary philosophy and the Christian faith', 47

'Recent views of Indian religion and philosophy', article by E. G. Parrinder, Iog

'Religion, The origins of', review article by E. G. Parrinder, 257

'Religion, The structure of', article by John E. Smith, 63

'Religious images, Truth claims for', article by A. R. Gualtieri, I5I

'Religious language as symbolism', article by J. Heywood Thomas, 89

'Religious traditions, The major: Recent re-assessments', review article by Trevor Ling, 249

Roberts, T. A., article: 'Gospel historicity: Some philosophical observations', 185

-review article: 'A defence of orthodoxy', 24I

SMART, Ninian, article: 'Interpretation and mystical experience', 75

SмITH, John E., article: 'The structure of religion', 63

'Structure of religion, The', article by John E. Smith, 63

'Supernatural, On excluding the', article by T. R. Miles, I4I

'Symbolism, Religious language as', article by J. Heywood Thomas, 89

'Theological methodology of John Oman and H. H. Farmer, The', article by Thomas A. Langford, 229

Thomas, J. Heywood, article: 'Religious language as symbolism', 89

'Truth claims for religious images', article by A. R. Gualtieri, I 5I

WERBLowsky, R. J. ZWI, article: 'On the mystical rejection of mystical illuminations', I 77

Williams, C. J. F., article: 'Aristotle and corruptibility: A discussion of Aristotle De Caelo I, xii, (Part I) 95, (Part II) 203 


\section{SUBSCRIPTIONS}

Orders may be sent to any bookseller or subscription agent, or direct to Cambridge University Press, Bentley House, 200 Euston Road, London N.W.I. Subscriptions in the USA and Canada should be sent to the American branch of the Press, 32 East 57 th Street, New York, N.Y.10022, USA. Each volume is published in two parts, appearing in October and April. The subscription price is 50s. net, including postage, in the UK (\$9.50 in the USA). Single parts are available at 30 . net in the UK (\$5.50 in the USA), plus postage.

Claims for non-receipt of copies will not be entertained if they are made more than four months after publication.

\section{Notes FOR \\ CONTRIBUTORS}

I. All contributions and books for review should be sent to the editor, Professor H. D. Lewis, King's College, Strand, London, W.C.2.

2. Contributions should normally be in English and should preferably be typewritten (double-spaced on quarto paper). Contributors should keep a copy themselves for use when correcting proofs.

3. Submission of an article is taken to imply that it has not previously been published, or is not being considered for publication elsewhere.

4. All contributors receive $5^{0}$ free separates. 


\section{Religious Studies}

Volume 1 , Number 2, 1966

\section{CONTENTS}

HEPBURN, R. W.

Questions about the Meaning of Life

MILES, T. R.

On Excluding the Supernatural

GUALTIERI, A. R.

Truth Claims for Religious Images

LING, TREVOR

Buddhist Mysticism

WERBLOWSKY, R. J. ZWI

On the Mystical Rejection of Mystical Illuminations

ROBERTS, T. A.

Gospel Historicity: Some Philosophical Observations

WILLIAMS, C. J. F.

Aristotle and Corruptibility: A Discussion of Aristotle De Caelo Part II : I, xii

BRANDON, S. G. F.

The Origin of Death in some Ancient Near Eastern Religions LA YGFORD, THOMAS A.

The Theological Methodology of John Oman and H. H. Farmer

Review articles

ROBERTS, T. A.

A Defence of Orthodoxy

LING, TREVOR

The Major Religious Traditions: Recent Re-assessments

PARRINDER, E. G.

The Origins of Religion

\section{CAMBRIDGE UNIVERSITY PRESS}

Bentley House, 200 Euston Road, London, N.W. I

American Branch: 32 East 57th Street, New York, N.Y. 10022

30s. net $\$ 5.50$ in U.S.A. Subscription Price 50 s. $\$ 9.50$ in U.S.A. 